\title{
Detecting Service quality influence using DINESERV model: A study with the reference to restaurants in Dhaka city
}

\author{
ANIKA NASHAT MATIN ${ }^{1}$ \\ Research Scholar, Lovely Professional University, Phagwara, India \\ DR. VEER P. GANGWAR ${ }^{2}$ \\ Faculty, Mittal School of Business, Lovely professional University, Phagwara, India \\ MD. SIDDIKUR RAHMAN ${ }^{3}$ \\ Faculty, Department of Management Studies, Comilla University, Bangladesh
}

MUHAMMAD SYEDUZZAMAN ${ }^{4}$

Associate Professor, Department of management, Mohammadpur Kendriya College,Dhaka, Bangladesh

PROFESSOR MD YAMIN HASSAN ${ }^{5}$

Principal, Crescent College, Hatigaon, Guwahati-781022, Assam,India

\begin{abstract}
Number of studies related to assessing service quality through Service quality gap model, known as SERVQUAL model in tourism and hospitality industries is seen either originally or with developed version. The main aim of this study is focused assessing empirically on the developed version of SERVQUAL model for measuring the service quality for restaurant services known as DINESERV, in the context of restaurant services in Dhaka city, Bangladesh. The comprised 29 attributes of SERVQUALL model is DINESERV, that is used for designing the questionnaires in this study, which aimed to measure the gap between expectation and perception level of customers in restaurant service. However, 110 valid questionnaires from 150 has been statistically analyzed in SPSS20. This empirical study makes a glance that 25 indicators have rooms to make more improvement due to persisting gap between expectations and perceptions, meanwhile, results and findings have been complied with the identification of strength and weakness of service quality of selected oldest restaurants of Dhaka city, who can uphold their dignity through the possible suggestions from this study.
\end{abstract}

Keywords: DINESERV, SERVQUAL, service quality, restaurants, Dhaka city. 


\section{Introduction}

Service quality in any organization is the most recognized and important factor to be considered. Service quality is such factor for service providers that have a direct impact on customer. Service quality brings the result of comparison among the expectations about service and perceptions on the performed service that is given to customers (Chun \& NyamOchir, 2020). Remembering the fact of impact of service quality in customer satisfaction and higher profitability, service providers acknowledge experiences from many sides to measure and to improve service quality. Service providers try to retain their customers to be in this competitive market. Service quality has been emerged and recognized as the key strategy value for gaining competitive advantages to business (Lee et al., 2016). Development of complex set of restaurant attributes are constantly focusing by the restaurant owners for providing best dining experiences among customers. Variety of measurement tools and techniques are deployed to assess service quality among which SERVQUAL by Parasuraman et al. (1988) is mostly adopted in previous studies. However, to measure service quality in restaurant settings the most fit and reliable instruments DINESERV, developed by Stevens et al. (1995), which is a modified version of SERVQUAL dimensions comprised of 29 instruments. The modified version DINESERV is used in this study to empirically assess the service quality in ten restaurants which is fifteen years old and running with dignity, in Dhaka city.

Restaurant industry is highly booming its growth towards business sector of Bangladesh. According to Bangladesh Bureau of Statistics (BBS) on the FY2019, the size of sector is Tk.2.85 billion (Bangladesh, 2019). However, Dhaka is assembled with around 1000 restaurants listed from both the South and North city corporations of Dhaka metropolitan (Abrar, 2020, June 13). Modified version of DINESERV is used in this study to empirically assess the service quality in ten restaurants in Dhaka city, specifically fifteen years old. This study is intended to bring the most influential service quality dimensions that help these restaurants to run successfully in industry as well DINESERV will point out those factors that is needed to be improvised in service quality within, which will also carry out as recommendations for other kind of restaurants that is struggling to establish. Studies on assessing service quality in restaurant industry of Bangladesh have been focused by many researchers, specializing in some certain dinning arrangements: (Hossain et al., 2018; Hossain, 2019; Huda \& Islam, 2019; Islam et al., 2018; Rahman et al., 2012). Most of the studies are influencing in assessing service quality through SERVQUAL model and very few using DINESERV, whereas, findings of this study through DINESERV model focusing the oldest restaurants of mega city Dhaka is very much time befitting for restaurant owners to develop a deep insights of understanding with customers to uphold their dignity, that will guide other type of restaurant owners of country and same type of international within. This study is classified under the brief review of service quality measurement in restaurant industry, and then it goes with the methodology part with discussions of findings and followed by the conversations with ends with limitation that directs future scope of the study. 


\section{Review of Literature}

Service quality is attempted to be the most important issue regarding any business issues. Managing service quality is a matter of concern (Gogoi \& Jyoti, 2020). It is needed for service quality to enhance business to further. Service quality is represented in various researches in order to fulfill customers' demands and to match such with service providers (Markovic et al., 2013). Service quality model is mostly known as SERVQUAL is a multiitem scale developed to assess customer perceptions of service quality in service oriented organization or retail business. SERVQUAL took shape and was developed during the 88's byZeithaml et al. (1988), originally developed from the GAP model. These dimensions are mainly focused on human aspects of service delivery, for measuring consumer perception of service quality which is known as SERVQUAL, where the dimensions collapsed from 10 to 5 as from early research of the same-

Tangibles- physical facilities, appearance of personnel and equipment

Reliability- ability to perform the promised service dependable ad accurately

Responsiveness- willingness to help customers and provide prompt service

Assurance-ability of the organizations employees to inspire trust and confidence in the organization through their knowledge and courtesy

Empathy- personal attention given to customer.

SERVQUAL can help to assess the customers' satisfaction and service quality perceptions in various ways. It focusses on the core areas that are needed to develop in service quality for the organization where the management need to focused as it is already said earlier that, customer satisfaction in given service quality is important to exist in this competitive economy market.

Customers perception of service experiences are key elements for the success of every service organizations (Laming \& Mason, 2014) and the degree in which customers perceive every Service's attributes directly affect customer's attitude when they are asked to issue an overall judgment about their experience of the Quality of Service delivered (Brida et al., 2016). Hence, Knutson et al. (1996)stated perceived service quality as collaboration between three independent variables as normative expectations predictive expectations and actual service quality which actually lead to the least expectations of customers on what should happen, the worth able perceptions of actual service.

According to Adeinat (2019), DINESERV is at big use of measuring restaurants performance because of its capacity to distinguish overall the quality scores as whole with similar service under performance. DINESERV is a very well established and trustworthy and very easy measurement tool of measuring customers satisfaction towards restaurant's service. In many research, shortage of measuring service quality with SERVQUAL several limitations have come up.According to Hansen (2014), the objective of DINESERV is to provide restaurant operators and its owners a path to have a concrete knowledge about their service quality and its acceptance to customers. It has an adoption of dimensions from SERVQUAL model and made fit into restaurant industry, developed by Knutson et al. (1996), whereas it is much noticeable uses of SERVQUAL in various studies of : (Fu \& Parks, 2001; Marković et al., 2010; Ryu \& Han, 2010; Wu \& Liang, 2009). Meanwhile, DINESERV is much more identified as inspiration of SERVQUAL model that finds gap theory model comprises with 
29 items and a performance -based measurement tool to measure the perceptions of service outcomes (Keith \& Simmers, 2013). The 29 items survey instrument includes 10 items contains in tangibile, 5 in reliability, 3 in responsiveness, 6 in assurance and 5 in empathy.

\section{Methodology}

This study is going to empirically assess the service quality of ten restaurants of fifteen years old; settings in Dhaka city. Level of perceptions and expectations among restaurants services will be empirically tested in this study. Through the following research objectives, this study is intended to look forward from the selected ten restaurants of Dhaka city.

1. To identify the degree of customers' expectations regarding restaurants service quality.

2. To determine the degree of customers' perceptions regarding restaurants service quality.

3. To examine the alterations between perceived and expected service from restaurants. Following hypotheses have been framed in terms of research objectives:

$\mathbf{H}_{1}$ : Empathy is the most important expected service quality dimension of restaurants settings in Dhaka city.

$\mathbf{H}_{2}$ : Empathy is the most important perceived service quality dimension of restaurants settings in Dhaka city.

H3: A significant difference persists among expected and perceived service quality in restaurant settings in Dhaka city.

These questions were measured on the basis of 29 attributes of DINESERV model (Knutson et al., 1996), that consists in extended five dimensions of DINESERV dimensions: tangibles, reliability, empathy, assurance, responsiveness on ten selected restaurants in Dhaka city which are fifteen years old, respectively. The given statement have been weighed using five point likert scale with strongly disagree as 1 and strongly agree as 5. The 150 questionnaires distributed to selected ten restaurants with the help of restaurants staffs to those participants that have been willingly participated after dining experience, with the availability of local food, known as 'deshi food' and shahi food which is known as rich food as well. Data analysis based on number of 110 valid questionnaires, with the response rate $73.3 \%$. A convenience sampling method deployed to collect data. Statistical package of SPSS 20 used for analyzing data. To encounter the surveys areas, descriptive, bivariate (paired sample ttest) statistical analysis were deployed as well (Kothari, 2004). Descriptive statistics used to get the first two answers that measured the demographic profile to examine the service quality expectations and perceptions and the last answer was detected using paired sample ttest to know the how the two scores of perceptions and expectations of service quality are significantly different.

\section{Research Findings}

Through descriptive statistical analysis, respondents of demographic variables have been resulted as shown in the Table 1, whereas important demographics has been chosen, as income, gender response, different age group matters in response of satisfaction from service quality of restaurants (Mhlanga et al., 2015). This study has given importance to Gen X, Gen $\mathrm{Y}$ and Gen $\mathrm{Z}$ as aged group to persist real scenario and detection of gap from taking certain age group in studies of (Osman et al., 2018; Polas et al., 2020). 
Table1: Demographic characteristics of respondents $(\mathrm{N}=110)$.

\begin{tabular}{|l|c|l|l|}
\hline \multicolumn{1}{|c|}{ Particulars } & Percentage & Particulars & Percentage \\
\hline Gender & & \multicolumn{1}{|c|}{ Age } & \\
Male & $46.4 \%$ & $20----30$ & $8.2 \%$ \\
Female & $51.8 \%$ & $30----40$ & $19.1 \%$ \\
Wish not to answer & $1.8 \%$ & $40----50$ & $38.2 \%$ \\
& & $50----60$ & $20.9 \%$ \\
& & $60-$ above & $13.6 \%$ \\
\hline Education Level & & Occupation & \\
College & $35.5 \%$ & Susiness & $20.9 \%$ \\
University & $59.1 \%$ & Student & $44.5 \%$ \\
None & $5.5 \%$ & & $34.4 \%$ \\
& & & \\
Income (BDT) & & & \\
15000---- 20000 & $21.8 \%$ & & \\
20000----30000 & $38.2 \%$ & & \\
$30000----a b o v e$ & $40 \%$ & & \\
& & & \\
\hline
\end{tabular}

The above demographic characteristics previewed female respondents $(51.8 \%)$ which slightly outnumbered male respondents (46.4\%). This study also preferred with respect, those respondents who do not wish to mention gender and that respondent counted (1.8\%) as valued customers. Education levels were mostly young generation of university level and college level, whereas some respondents were also found not having educational background. However, customers' perceptions and expectation level measured on five-point likert scale where the higher the scores, the results are positively entitled for the research. Bellow Table (2) are the results of bivariate statistical analysis inspired from Hossain et al., (2018); Markovic et al., (2013), following future suggestions made on such studies, whereas original attributes of DINESERV Knutson et al. (1996)that has been comprised in this study as this is the very first scenario in the context of restaurants of Dhaka city, in an intention with the best possible output through comparison for research results of customers' expectations and perceptions are illustrated.

Table 2: Expectations and perceptions of customers of service quality in restaurants of Dhaka city.

\begin{tabular}{|l|l|l|l|l|l|l|}
\hline & \multicolumn{2}{l|l}{ Expectations } & \multicolumn{2}{l|}{ Perceptions } & & \\
\hline Attributes & Mean a & SD & Mean ${ }^{\text {b }}$ & SD & Gap & t-value \\
\hline $\begin{array}{l}\text { TA1- Visually attractive building } \\
\text { exteriors and parking areas. }\end{array}$ & 2.45 & 0.992 & 3.27 & 0.877 & -0.82 & $-6.612^{*}$ \\
\hline TA2- Visually attractive dining areas & 3.29 & 1.112 & 3.26 & 0.925 & -0.03 & .189 \\
\hline
\end{tabular}




\begin{tabular}{|c|c|c|c|c|c|c|}
\hline $\begin{array}{l}\text { TA3- Staff members are neat and clean } \\
\text { with well dress up. }\end{array}$ & 2.83 & 1.148 & 2.85 & 0.727 & 0.02 & $-3.289^{*}$ \\
\hline $\begin{array}{l}\text { TA4- Décor is maintaining with its image } \\
\text { and price is in range. }\end{array}$ & 3.09 & 1.17 & 4.1 & 0.729 & 1.01 & 1.637 \\
\hline TA5- Menu with easily readable & 3.73 & 0.845 & 3.32 & 0.908 & -0.41 & $-3.358^{*}$ \\
\hline $\begin{array}{l}\text { TA6- Visually attractive menu that } \\
\text { results the restaurants image. }\end{array}$ & 3.83 & 0.8 & 2.22 & 0.902 & -1.61 & $4.899^{*}$ \\
\hline $\begin{array}{l}\text { TA7- Comfortable dining area with space } \\
\text { to move around. }\end{array}$ & 3.23 & 0.699 & 2.14 & 0.67 & -1.09 & $8.282^{*}$ \\
\hline TA8- Rest rooms are clean all way & 2.23 & 0.725 & 3.05 & 0.696 & 0.82 & .897 \\
\hline TA9- Dining areas are clean. & 3.27 & 0.887 & 2.84 & 0.773 & -0.43 & $2.139^{*}$ \\
\hline $\begin{array}{l}\text { TA10- Seats are comfortable in dining } \\
\text { area. }\end{array}$ & 3.24 & 0.703 & 2.21 & 0.863 & -1.02 & $4.113^{*}$ \\
\hline Tangible (Mean) & 3.12 & & 2.93 & & -0.356 & \\
\hline RL 1- Serves in promised time. & 2.69 & 0.571 & 3.18 & 0.623 & 0.49 & $6.067^{*}$ \\
\hline RL2- Corrects mistakes quickly. & 2.59 & 0.494 & 3.88 & 0.775 & 1.29 & $-3.184^{*}$ \\
\hline RL3- Can be depend with consistency. & 3.45 & 0.5 & 4.51 & 0.714 & 1.06 & $-5.023^{*}$ \\
\hline RL4- Guests are accurately checked. & 2.48 & 0.52 & 3.42 & 0.828 & 0.94 & $-12.315^{*}$ \\
\hline RL5-Serves food as exactly ordered. & 2.93 & 1.073 & 2.33 & 0.869 & -0.6 & $-6.272^{*}$ \\
\hline Reliability (Mean) & 2.83 & & 3.46 & & 0.636 & \\
\hline $\begin{array}{l}\text { RN1- Employees help each other during } \\
\text { busy time to maintain prompt and quality } \\
\text { of service. }\end{array}$ & 2.96 & 0.716 & 4.51 & 0.714 & 1.55 & $-4.584^{*}$ \\
\hline RN2- Deliver quick service & 2.54 & 0.631 & 3.42 & 0.828 & -0.88 & $6.032^{*}$ \\
\hline $\begin{array}{l}\text { RN3- Deliver extra effort to attend } \\
\text { special request. }\end{array}$ & 2.66 & 0.494 & 2.33 & 0.869 & -0.38 & $-11.284^{*}$ \\
\hline Responsiveness (Mean) & 2.72 & & 3.42 & & 0.1 & \\
\hline $\begin{array}{l}\text { AS1- Ability of employees to answer } \\
\text { your queries entirely. }\end{array}$ & 2.84 & 0.711 & 2.61 & 0.607 & -0.23 & -.842 \\
\hline $\begin{array}{l}\text { AS2- You are comfortable and confident } \\
\text { dealing with employees. }\end{array}$ & 3.56 & 0.516 & 1.89 & 0.817 & -0.95 & $-13.017^{*}$ \\
\hline $\begin{array}{l}\text { AS3- Personal who attends to inform } \\
\text { about menu items, ingredients and } \\
\text { preparation method. }\end{array}$ & 4.22 & 0.722 & 4.22 & 0.669 & -0.11 & $9.385^{*}$ \\
\hline $\begin{array}{l}\text { AS4- You feel safe during your visiting } \\
\text { hours. }\end{array}$ & 3.53 & 0.906 & 3.14 & 0.772 & -0.39 & $-8.899^{*}$ \\
\hline $\begin{array}{l}\text { AS 5- Personnel are well trained, } \\
\text { experienced and capable. }\end{array}$ & 3.31 & 0.832 & 2.15 & 0.68 & -1.16 & $11.281^{*}$ \\
\hline $\begin{array}{l}\text { AS6- Management supports employees to } \\
\text { ensure their best performance. }\end{array}$ & 3.95 & 0.913 & 2.59 & 0.805 & -1 & $12.203^{*}$ \\
\hline Assurance (Mean) & 3.57 & & 2.75 & & -0.64 & \\
\hline
\end{tabular}




\begin{tabular}{|l|l|l|l|l|l|l|}
\hline $\begin{array}{l}\text { EM1- Rather considering rules and } \\
\text { regulations, personal handles your } \\
\text { individual needs and wants. }\end{array}$ & 4.86 & 0.761 & 3.29 & 0.746 & -1.57 & $6.838^{*}$ \\
\hline EM2- You are treated specially. & 3.16 & 0.784 & 3.61 & 0.755 & 0.45 & $5.845^{*}$ \\
\hline $\begin{array}{l}\text { EM3- Personal needs and wants are } \\
\text { anticipated. }\end{array}$ & $3 . .86$ & 0.804 & 3.37 & 0.648 & -0.49 & $2.155^{*}$ \\
\hline $\begin{array}{l}\text { EM4- Employees reassure for any kind of } \\
\text { misconduct and treat with sympathy. }\end{array}$ & 3.86 & 0.76 & 3.57 & 0.78 & -0.29 & $-2.243^{*}$ \\
\hline $\begin{array}{l}\text { EM5- Occupy the customers best } \\
\text { attention in sentiment. }\end{array}$ & 4.22 & 0.711 & 3.59 & 0.682 & -0.63 & $2.585^{*}$ \\
\hline Empathy (Mean) & $\mathbf{3 . 9 9}$ & & $\mathbf{3 . 4 9}$ & & $\mathbf{- 0 . 5 0 6}$ & \\
\hline Total mean (29 attributes) & $\mathbf{3 . 2 5}$ & & $\mathbf{3 . 2 1}$ & & $\mathbf{- 0 . 1 5}$ & \\
\hline
\end{tabular}

Note: Ranges of expectation Mean 1 to 5; ranges of perceptions Mean ${ }^{\mathbf{b}} 1$ to 5; SD-standard deviation and *t-test (2-tailed Sig.) $\mathrm{p}<0.05$.

In comparing research findings of customers 'expectation and perceptions of restaurants service quality around Dhaka city where it can be decided as customers' perceptions is lower than expectations. Overall gap resulted as -0.15 which indicated as the peak level of service quality. The largest gap identified in assurance (-0.64) and lowest gap identified in tangible mean (-0.35). In sum up of total 8 out of 29 gaps indicating positively that customers' expectations have been exceed and they are satisfied in regard of these attributes. Meanwhile, other 21 gaps that represent negatively have more scope to be developed. In restaurant services, the dimensions of empathy resulted the highest mean shore in the expectation (3.99) an in perception as well (3.99) scale, irrespective to that, the lowest mean score resulted in the dimension responsiveness (2.75). In terms of highest expectation, items recognized as occupy the best customers attention in sentiment, rather considering rules and regulations personnel handles individuals needs and wants, personal needs and wants are anticipates, employees reassures of any kind of mistakes, menu easily readable and menu that that goes with image of restaurants. From the perception point of view, highest items recognized as personnel attends customers quarries despite of rules and regulation, customers are treated specially, employees help each other during busy time, décor is maintaining with price, can be depend with consistency and corrects mistakes quickly. On the other hand, the lowest expectation items were recognized as, rest rooms are clean all way, seats are comfortable in dining area, staff members are neat and clean, serves in promised time, corrects mistakes quickly, guests are accurately cheeked, serves food exact orders, deliver quick service, deliver extra effort to attend special request, ability of employees to answer queries entirely. In the perception, items that are ranked in lowest are: comfortable dining area, customers are comfortable while dealing with employees, personnel are well trained and experiences, management support to employees to deploy their best support, ability of employees to answer queries entirely, deliver extra effort to attend special request, serves food exactly ordered, seats are comfortable within dining area, dining areas are clean, comfortable dining areas with space to move, visually attractive menu with image and staff members are neat 
and clean. In the results of table 2, indicate that there are variations which are significant statistically, in the responses of mean of all 29 attributes. All 25 variables from 29 attributes of 5 dimensions were significant statistically that confirms hypothesis $\mathrm{H}^{3}$.

\section{Conclusion}

The aim of this research paper was to investigate empirically service quality of ten restaurants around Dhaka city, the capital of Bangladesh, through three research objectives. Statistical analysis has been done to identify the level of expectations and perceptions, as well to determine the differences among scores. Consequently, all attributes of customers expectations and perceptions of restaurants service quality of Dhaka city were examines empirically. Therefore, all hypothesis and research questions were tested and answered. Descriptive analysis suggests from the results that the items that are importantly belongs to empathy dimensions with highest scores of means. This indicates that hypothesis $\mathrm{H}^{1}$ and hypothesis $\mathrm{H}^{2}$ is accepted.

The results of analysis from t-test, which showed differences that is significant among expectations and perceptions, where the majority of attributes in a room of more improvement. However, mangers of restaurants need to have special attention different demographic attitudes of customers as satisfaction differs from each characteristics and that is what is needed by the managers through their service to be in the competition.

Meanwhile, expectations and perceptions of another largest division of Bangladesh, known as Chattragram has been developed by Hossain (2019), which only focused fine dining and fast food restaurants, as well in the paper ofMarkovic et al. (2013), determined reliability as the most significant dimension in the restaurant settings of Croatia. Using DINESERV model for measuring service quality of restaurants in Dhaka city is being carried out for the first time through this study in Bangladesh. This study are significantly important for the management implication to carefully overlook on the subjects matters to so many negative impressions on perceptions items that will help to sustain in competitive economy.

However, limitations of this study are selection of restaurants can be more with lowest time framing. One more limitation can be determined of taking only domestic customers are respondents whereas, such study can take further, with both national and international participants in more restaurants, which might flourish the results more generalize as DINESERV Knutson et al. (1996) is the most fittest instruments to measure service quality in restaurant settings.

\section{References}

Abrar, N. (2020, June 13). Youth-led restaurants striving to survive. The Financial Express. https://thefinancialexpress.com.bd/publicleducation/youth-led-restaurants-striving-tosurvive-1591806332

Adeinat, I. (2019). Measuring service quality efficiency using DINESERV. International Journal for Quality Research, 13(3), 591-604. 
Bangladesh, B. S. Y. B. (2019). Bangladesh Bureau of Statistics: Dhaka. In: Bangladesh.

Brida, J. G., Moreno-Izquierdo, L., \& Zapata-Aguirre, S. (2016). Customer perception of service quality: The role of Information and Communication Technologies (ICTs) at airport functional areas. Tourism Management Perspectives, 20, 209-216.

Chun, S.-H., \& Nyam-Ochir, A. (2020). The effects of fast food restaurant attributes on customer satisfaction, revisit intention, and recommendation using DINESERV scale. Sustainability, 12(18), 7435.

Fu, Y.-Y., \& Parks, S. C. (2001). The relationship between restaurant service quality and consumer loyalty among the elderly. Journal of Hospitality \& Tourism Research, 25(3), 320-326.

Gogoi, D., \& Jyoti, B. (2020). Service quality measures: How it impacts customer satisfaction and loyalty. International Journal of Management (IJM), 11(3), 354-365.

Hansen, K. V. (2014). Development of SERVQUAL and DINESERV for measuring meal experiences in eating establishments. Scandinavian Journal of Hospitality and Tourism, 14(2), 116-134.

Hossain, M., Lecturer, H., \& Marketing, I. (2018). Service Quality Assessment in Hospitality Industry: A Focus on Restaurant Services in Chittagong. 2227-1287.

Hossain, M. S. (2019). Impact of Perceived Service Quality dimensions on Customer Satisfaction in Hospitality Industry. Global Review of Research in Tourism, Hospitality and Leisure Management (GRRTHLM) An Online International (DoubleBlind) Refereed Research Journal, 5(1), 683-699.

Huda, E., \& Islam, S. (2019). Factors Affecting Services Quality of Restaurants Business: A Study on Dhaka City. Journal of Business, 40(2).

Islam, D. N., Ameen, M., Rashid, A., Kabir, T., Ahmed, S., \& Nazrul, T. (2018). Factors Influencing the Selection of Restaurant for Dining in Dhaka City of Bangladesh. Global Journal of Management and Business Research, 18, 31-38.

Keith, N. K., \& Simmers, C. S. (2013). Measuring hotel service quality perceptions: The disparity between comment cards and LODGSERV. Academy of Marketing Studies Journal, 17(2), 119.

Knutson, B. J., Stevens, P., \& Patton, M. (1996). DINESERV: Measuring service quality in quick service, casual/theme, and fine dining restaurants. Journal of hospitality \& leisure marketing, 3(2), 35-44. 
Kothari, C. R. (2004). Research methodology: Methods and techniques. New Age International.

Laming, C., \& Mason, K. (2014). Customer experience-An analysis of the concept and its performance in airline brands. Research in Transportation Business \& Management, $10,15-25$.

Lee, L., Lee, M. J., \& Dewald, B. (2016). Measuring the customers' perception of tangible service quality in the restaurant industry: an emphasis on the upscale dining segment. Journal of Foodservice Business Research, 19(1), 21-38.

Markovic, S., Komsic, J., \& Stifanic, M. (2013). Measuring service quality in city restaurant settings using DINESERV scale. Recent Advances in Business Management and Marketing, 181, 176-181.

Marković, S., Raspor, S., \& Šegarić, K. (2010). Does restaurant performance meet customers' expectations? An assessment of restaurant service quality using a modified DINESERV approach. Tourism and Hospitality Management, 16(2), 181-195.

Mhlanga, O., Hattingh, Z., \& Moolman, H. J. (2015). Influence of demographic variables on customers' experiences in formal full-service restaurants in Port Elizabeth, South Africa. Tourism: An International Interdisciplinary Journal, 63(2), 143-160.

Osman, A. R., Hossain, T., \& Sarkar, J. B. (2018). Investigating university students' satisfaction with on-campus cafeteria services: an empirical study in perspective of private university. Asian Journal of Empirical Research, 8(6), 225-237.

Parasuraman, A., Zeithaml, V. A., \& Berry, L. (1988). SERVQUAL: A multiple-item scale for measuring consumer perceptions of service quality. 1988, 64(1), 12-40.

Polas, M. R. H., Raju, V., Hossen, S. M., Karim, A. M., \& Tabash, M. I. (2020). Customer's revisit intention: Empirical evidence on Gen-Z from Bangladesh towards halal restaurants. Journal of Public Affairs, e2572.

Rahman, M., Kalam, A., Mohammad, H., Rahman, M., \& Abdullah, M. (2012). The Influence of Service Quality and Price on Customer Satisfaction: An Empirical Study on Restaurant Services in Khulna Division. Research Journal of Finance and Accounting, 3, 8-15.

Ryu, K., \& Han, H. (2010). Influence of the quality of food, service, and physical environment on customer satisfaction and behavioral intention in quick-casual restaurants: Moderating role of perceived price. Journal of Hospitality \& Tourism Research, 34(3), 310-329. 
Stevens, P., Knutson, B., \& Patton, M. (1995). DINESERV: A tool for measuring service quality in restaurants. The Cornell Hotel and Restaurant Administration Quarterly, $36(2), 5-60$.

Wu, C. H.-J., \& Liang, R.-D. (2009). Effect of experiential value on customer satisfaction with service encounters in luxury-hotel restaurants. International Journal of Hospitality Management, 28(4), 586-593.

Zeithaml, V. A., Berry, L. L., \& Parasuraman, A. (1988). Communication and control processes in the delivery of service quality. Journal of marketing, 52(2), 35-48. 